\title{
The Development of Teaching and Learning Methods in Hadits in the Islamic Education Program at Madrasah Irsyad Zuhri Al-Islamiah Singapore
}

\author{
Rohana Binte Ithnin \\ Wakil Mudir Madrasah Irsyad Zuhri Al-Islamiah \\ Singapura \\ rohana.irsyad@gmail.com
}

\author{
Ulil Amri Syafri \\ Dosen Universitas Ibn Khaldun (UIKA) Bogor \\ ulamris@gmail.com
}

\author{
Irfan Syauqi Beik \\ Dosen Institut Pertanian Bogor (IPB) \\ qibeiktop@yahoo.com
}

\begin{abstract}
The development of teaching and learning methods is currently an important phenomenon in the education field. This phenomenon is more likely to be influenced by technological advancement in teaching and learning methods that have been commonly used in the education field. The development of teaching and learning methods could also be applied in Islamic education program, particularly in the teaching of Hadits in schools. In this investigation, Madrasah Irsyad Zuhri Al-Islamiah was chosen as the object of research. The investigation found that development of teaching and learning of Hadits is required due to limited lesson time allocated for the teaching of subject. Thus, it is hoped that the teaching and learning of Hadits will contribute to the holistic development of students' character and education, extending beyond the cognitive level of the subject.
\end{abstract}

Key words: Development of teaching and learning methods, teaching and learning methods, Islamic religious education, Hadits

\section{INTRODUCTION}

In the Islamic education field, the development of student-centred teaching and learning method has long taken place. The teacher-centered concept, which is at the core of Islamic education, does not impedes education practitioners to explore and develop their teaching and learning methods. Generally, they vary the learning tools or media that they use during the teaching and learning process.

One of the courses offered by Madrasah Irsyad Zuhri Al-Islamiah in its Islamic education curriculum is Hadits. The objective of teaching the course is to develop students' Islamic characters. Those aspects include to understand, practice and apply knowledge of Hadits. Hence, this course is critical to students' character development and the concept of holistic education uphold by Madrasah Irsyad Zuhri Al-Islamiah

However, the preliminary observation outcome had shown that the passing percentage in Hadits for secondary 3 and 4 students fail to reach the $100 \%$ as targeted at the beginning of the academic year despite improvement in Hadits memorization and consistent drilling practice in answering Sijil Thanawi Empat (STE) questions. In other words, these results reflected that the teaching only focused on the cognitive level of students' understanding of Hadits. It means that the students just learn the Hadits purely through rote method. Thus, they failed to achieve the deep understanding of Hadits. The results also reflected how the current teaching and learning method is not able to engage the affective and psychomotor domains in students' learning process. This situation is indeed not in line with the aims of holistic education which is to develop the cognitive, affective and psychomotor domains of the individual learner.

Therefore, this research aims to formulate the suitable teaching and learning methods for Hadits taught at Madrasah Irsyad Zuhri Al-Islamiah. The method is to ensure that Hadits is not merely knowledge (cognitive) learned by the students but also understood and reflected (affective) as well as practised (psychomotor) by them.

\section{Development of Teaching and Learning methods}

The development of teaching and learning method is gaining concurrent importance along with the advancements in technology, more specifically cyber technology that has been continuously evolving since the 21 st century. Therefore, it is not surprising that the extensive power of the Internet has been influencing and still influences conventional teaching and learning methods in the education field such as the use of multimedia tools and online teaching and learning platforms. Nearly every education institution in developed countries applies technology-based teaching and learning for education purposes. 
Therefore, teachers are expected to develop their skills in creating new teaching and learning media [1]. It means that the teachers are not the main transmitter of knowledge of the subject taught. The technology-based teaching emphasizes more on modern technology such as televisions, cassette, Internet, blog among many others. Thus, rapid advancements in technology is no longer an obstacle for teachers, but an opportunity to further improve their professional competency to newer heights [5].

\section{Hadits: A Component of Islamic Education}

Hadits in education institutions serves as an integral component of Islamic education. Islamic education is a cluster subject developed from basic teachings of Islam. From its content knowledge, Islamic education is paramount to the development of students' moral character [7]. Therefore, effectiveness of Islamic education in Madrasah plays an important role for the spiritual development of a harmonious society.

\section{METHOD}

This research is a field research as its execution and data collection were carried out through field observation [8]. Qualitative approach was adopted in this research: it was an observation process executed in the field in its natural state without any form of manipulation. Qualitative research yielded descriptive data in the form of verbal/written as well as observation of the subjects' behaviour [3].

Overall, the data were obtained through observation, video-recording, photo-taking, interaction with secondary 3 and 4 students of Madrasah Irsyad Zuhri Al-Islamiah and interviews with relevant informants. In addition, additional data were collected to further support the primary data. Those were brochures, translated textbooks as well as the Madrasah's website. Other relevant data were books related to education development, teaching and learning methods as well as qualitative research method.

The data analysis techniques were document analysis, critical analysis and advanced interpretation to constructively develop new concepts. Each document obtained through data collection was analysed, identified and categorised accordingly. Additionally, data triangulation was also conducted i.e. analyses of observation data, document and interview data.

\section{RESULT \& DISCUSSION}

\section{The Teaching and Learning of Hadits in Madrasah Irsyad Zuhri Al-Islamiah}

The research outcomes showed that the main challenge for Hadits teachers was the limited allocated time for this course per week, that was one hour weekly. Another arising challenge was the student's different learning pace in one class. The other issue was the use of Arabic language by the teachers and that adversely affected the students' interest in the subject.
As a result, the teaching and learning process became results-oriented learning. To put it in another way, the final students' grades from evaluative assessments - became more important than the process. As for the teachers, what was also important was that they had covered the determined syllabus and materials.

Table 1: 2014-2016 Secondary Hadits Target

\begin{tabular}{lcccc}
\hline \multicolumn{5}{c}{ YEAR OVERALL } \\
\hline & Level & $\begin{array}{c}\% \\
\text { Pass }\end{array}$ & $\begin{array}{c}\text { MSG } \\
\text { Medium } \\
\text { Subject } \\
\text { Grade }\end{array}$ & $\begin{array}{c}\text { Mumtaz } \\
\text { Syaraf } \\
\text { /Mumtaz } \\
\text { (Distinction) }\end{array}$ \\
\hline Mahzan/Rabia & S3 & 100 & 3.3 & 35 \\
\hline Mahzan/Azhari & S4 & 100 & 3.4 & 30 \\
\hline
\end{tabular}

The table above is the targeted grades for Hadits as set by Madrasah Irsyad Zuhri Al-Islamiah for secondary 3 and 4 students from 2014 to 2016. The students were expected to achieve $100 \%$ learning success with Medium Subject Grade around 3.3-3.4.

This standard was arranged in parallel with the standards of Sijil Thanawi Empat (STE). STE refers to the examination for the religious subject set by MUIS as a standard qualification of every student at the Madrasah.

Hadits' teachers, hence, aimed to facilitate students' achievement to reach the targets by employing teaching and learning methods, suitable for the situation and conditions of each class. The table below shows the actual results obtained from the internal examinations conducted by the school and compared with STE outcomes from 2014 to 2016.

Table 2: Passed percentage of Secondary 3 and 4 students of Madrasah Irsyad Zuhri Al-Islamiah

\begin{tabular}{|c|c|c|c|c|c|c|c|}
\hline & $\% \mathrm{P}$ & MSG & $\% \mathrm{~A}$ & & $\% \mathrm{P}$ & MSG & $\% \mathrm{~A}$ \\
\hline $\begin{array}{l}\text { S3 } \\
2014 \\
\text { Internal }\end{array}$ & 63.8 & 4.6 & 15.5 & $\begin{array}{l}\text { S4 } \\
2014 \\
\text { Internal }\end{array}$ & 73.2 & 4.05 & 28.6 \\
\hline $\begin{array}{l}\text { S3/4 } \\
2014 \\
\text { STE }\end{array}$ & 83.9 & 3.63 & 28.57 & & & & \\
\hline $\begin{array}{l}\text { S3 } \\
2015 \\
\text { Internal }\end{array}$ & 69 & 3.97 & 31 & $\begin{array}{l}\text { S4 } \\
2015 \\
\text { Internal }\end{array}$ & 83.9 & 3.29 & 44.6 \\
\hline $\begin{array}{l}\text { S3/4 } \\
2015 \\
\text { STE }\end{array}$ & 80.4 & 4.69 & 25 & & & & \\
\hline $\begin{array}{l}\text { S3 } \\
2016 \\
\text { Internal } \\
\end{array}$ & 78.6 & 4.43 & 7.1 & $\begin{array}{l}\text { S4 } \\
2016 \\
\text { Internal }\end{array}$ & 85.1 & 3.19 & 38.3 \\
\hline $\begin{array}{l}\text { S3 } \\
2016 \\
\text { STE }\end{array}$ & 88.5 & 3.66 & 31.15 & & & & \\
\hline
\end{tabular}

Based on the findings above, it could be concluded that the implemented method when teaching hadits carried out by Madrasah Irsyad Zuhri Al-Islamiah focused more on examinations, preparation of lesson 
plan and meeting the set target by ALIS department. In other words, students' performance in Hadits was solely measured from the cognitive aspect only while the affective and psychomotor aspects were overlooked. This contradicts the main purpose of holistic education which was to engage all three domains of the individual.

\section{Development of Teaching and Learning Method through the Flipped Classroom Model}

This paper, hence, would like to suggest a form of teaching and learning method to address the restriction of Hadits learning by applying technology as the teaching media. This method is known as the flipped classroom. Flipped (or inverted) classroom can generally be defined as "inverting the classroom. It means that activities that have traditionally taken place inside the classroom now would take place outside the classsroom". In other words, flipped classroom is a teaching and learning concept, the opposite of conventional methods of teaching and learning [4].

Flipped classroom not only excites the students but it also brings along a whole array of benefits. For instance, this model maximizes the student-centered learning concept during outside-the-classroom time and optimalize the teacher-centered learning role during inclass lesson period time.

This flipped classroom model opens more room for problem-based learning activities during lesson period as compared to conventional teaching and learning methods. Thus, it is not surprising that past research has shown that students' achievement is greatly influenced by changing from the conventional model to the flipped classroom model. According to the research conducted by Mason, Shuman \& Cook [6], teachers need not have to worry much about the quality of the media or learning materials used online because what is more important is that the content of the media is concise and easy to understand.

\section{Flipped classroom using Padlet}

This study applied Padlet as a medium in the flipped classroom model to facilitate the learning carried out outside the classroom. The use of Padlet is like the use of sticky notes in conventional classrooms. Padlet is also free, user-friendly across all technological devices and does not require much technical knowledge to operate it [2].

To begin, a teacher needs to go to www.padlet.com and creates a wall. Once the wall is set up, students are then able to contribute ideas or opinions and add videos/audio clips/links/image files etc. on the wall by clicking on it. Since Padlet uses real-time technology, all students could access and contribute to the wall at any one time [2].

The teaching and learning of Hadits through the flipped classroom using Padlet could be an alternative for the development of teaching and learning method in Madrasah Irsyad Zuhri Al-Islamiah in the future. With this approach, the one-hour lesson time per week could be fully optimized with interactive activities that encourage questions, discussion, and problem solving on concepts that needs a deeper and more refined understanding.

Apart from benefitting the students, the use of Padlet in the flipped classroom has a positive effect for teachers too. The one-hour lesson in class and the flipped classroom outside school hours provide room to stimulate the teacher's creativity and innovation. Furthermore, both in-class and on-line interaction could foster stronger teacher-student bond and hence facilitating healthy communication between both parties.

The flipped model classroom using Padlet conducted in the teaching and learning of Hadits, not only achieved the targeted learning but it also contributes to the development of the students' character to be more independent and responsible towards their learning progress. In addition, they would be more diligent to seek more information and practise exercises as parts of assignments and activities set for them. consequently, the three education domains could be easily achieved when the flipped classroom using Padlet was applied. This is in line with the vision of Madrasah Irsyad Zuhri AlIslamiah to develop students to be khalifah-fil-ard that are holistic.

\section{CONCLUSION}

Teaching and learning is an educational process that should be interactive to meet the learning objectives. Thus, it requires systematic and proper plans to ensure the process runs effectively. The process of teaching and learning continues to evolve along with the development of technology and development from readily-available theories to produce newer models of teaching and learning fitting the condition and situation of the process itself.

Therefore, teachers are expected to know how to use media provided by the school and to be more open to possibilities to use the media creatively and innovatively in accordance with the development and demands of the present time.

\section{REFERENCES}

[1] Arief, Zainal Abidin, Media \& Teknologi Pembelajaran Inovatif, Perspektif Paradigma Baru Dalam Pendidikan, Bogor: Graha Widya Sakti, 2012.

[2] Beth Fuchs, The Writing is on The Wall: Using Padlet for Whole-Class Engagement, Journal Loex Quarterly, Volume 40, University of Kentucky, 2014.

[3] Bungin, M Burhan, Penelitian Kualitatif: Komunikasi, Ekonomi, Kebijakan Publik dan Ilmu Sosial Lainnya, Yogyakarta, Rineka Cipta, 2007.

[4] Lage, Maureen J., Glenn J. Platt, and Michael Treglia, Inverting the Classroom: A Gateway to Creating an Inclusive Learning Environment, Journal of Economic Education, Vol.31/No.1, 2000. 
[5] Marno dan M. Idris, Strategi dan Metode Pengajaran: Menciptakan Keterampilan Mengajar yang Efektif dan Edukatif, Yogyakarta: Ar Ruzz Media, 2010.

[6] Mason, Gregory S., Teodora Rutar Shuman, and Kathleen E. Cook, Comparing the Effectiveness of an Inverted Classroom to a Traditional Classroom in an Upper-Division Engineering Course, Journal of IEEE Transactions On Education, Vol. 56, No. 4, November 2013

[7] Muhaimin, et. al., Paradigma Pendidikan Islam, Bandung: Remaja Rosdakarya, 2002.

[8] Moleong, Lexy J., Metode Penelitian Kualitatif, Bandung: Remaja Rosdakarya, 2009. 